\title{
Some Patients Experience Both Chronic Lymphocytic Leukemia And A Non-Hematologic Malignancy
}

\author{
${ }^{1}$ Eren Gündüz, ${ }^{1}$ Neslihan Andıç, ${ }^{2}$ Beyhan Durak Aras, ${ }^{1}$ Olga Meltem Akay \\ ${ }^{1}$ Osmangazi Üniversitesi Tıp Fakültesi Hematoloji Bilim Dalı, Eskişehir \\ ${ }^{2}$ Osmangazi Üniversitesi Tıp Fakültesi Tıbbi Genetik AD, Eskişehir \\ e-posta: erengunduz26@gmail.com
}

\begin{abstract}
SUMMARY: Cancer patients are often at increased risk for other malignancies due to shared risk factors or carcinogenecity of the treatment for prior malignancy. As survival rates for most malignancies are increasing, the number of patients with more than one malignancy is also increasing. In this report we evaluated our patients having both chronic lymphoytic leukemia (CLL) and a non-hematologic malignancy retrospectively. We had 11 patients having both CLL and a non-hematologic malignancy. We aimed to add new insights into the role of casual factors and treatment options by reporting our patients with CLL and a non-hematologic malignancy.

KEYWORDS: Chronic lymphocytic leukemia, cytogenetics, non-hematologic malignancy, risk factors
\end{abstract}

ÖZET: Kanser hastaları, ortak risk faktörleri ya da önceki malignite tedavisinin karsinojenik etkisiyle diğer maligniteler için artmış risk taşırlar. Çoğu malignite için sağkalım oranları arttı̆̆ından birden fazla malignitesi olan hasta sayısı da artmaktadır. Kronik lenfositik lösemi (KLL) de solid tümör ve diğer lenfoid malignitelerin riskinde artışla birliktelik gösterir fakat bu ilişkinin mekanizması net değildir. $\mathrm{Bu}$ yazıda KLL ve hematolojik olmayan maligniteli hastalarımızı geriye dönük olarak değerlendirdik. Hem KLL hem de hematolojik olmayan maligniteli 11 hastamız mevcuttu. Hastaların sadece klinik ve laboratuvar özelliklerini değil sitogenetik sonuçlarını da sunduk. Amacımız bu hastalardaki nedensel faktörlerin rolüne ve tedavi seçeneklerine katkı sağlamaktır.

ANAHTAR KELIMELER: Kronik lenfositik lösemi, hematolojik olmayan malignite, risk faktörleri, sitogenetik

\section{Introduction}

Cancer patients are often at increased risk for other malignancies due to shared risk factors or carcinogenecity of the treatment for prior malignancy (1). As survival rates for most malignancies are increasing, the number of patients with more than one malignancy is also increasing. As chronic lymphocytic leukemia (CLL) is predominantly the disease of elderly (2), it might be preceeded or followed by other malignancies more often than other cancers (3). We suggest that reporting more patients having both CLL and a nonhematologic malignancy can add new insights into the role of casual factors and treatment options.

Case Report: Records of 11 patients known to have CLL and a non hematologic malignancy diagnosis before or after CLL are evaluated retrospectively. Sex, age at CLL diagnosis, age at non hematologic malignancy, smoking habit, time between CLL and non hematologic malignancy, survival, cytogenetics, CLL Rai stage and treatment, non hematologic malignancy type, stage and treatment are evaluated. Survival is mentioned as the time between CLL diagnosis and death. Results for the evaluated parameters are summarized in Table 1. Laboratory parameters of patients are listed in Table 2. There was no statistically significant difference between the parameters at CLL diagnosis and at non hematologic malignancy diagnosis. Immunglobulin levels were recorded only in 4 patients and none of them had hypogammaglobulinemia. Direct coombs test results were recorded in 5 of the patients. Only one patient had a positive (1+) test result without hemolysis and the other results were found negative. None of the patients died because of CLL related causes. 
Table 1

Patient Characteristics

\begin{tabular}{|c|c|c|c|c|c|c|c|c|c|c|c|c|}
\hline \multicolumn{2}{|l|}{ Patient no } & 1 & 2 & 3 & 4 & 5 & 6 & 7 & 8 & 9 & 10 & 11 \\
\hline \multicolumn{2}{|l|}{ Sex } & Male & Female & Male & Female & Male & Female & Male & Female & Male & Female & Male \\
\hline \multicolumn{2}{|c|}{ Age at CLL diagnosis } & 74 & 59 & 62 & 66 & 67 & 63 & 69 & 73 & 59 & 75 & 56 \\
\hline \multicolumn{2}{|c|}{$\begin{array}{l}\text { Age at non hematologic } \\
\text { malignancy diagnosis }\end{array}$} & 67 & 65 & 64 & 68 & 67 & 71 & 80 & 73 & 60 & 65 & 57 \\
\hline \multicolumn{2}{|c|}{ Comorbidities } & None & $\begin{array}{l}\text { Hyperten } \\
\text { sion }\end{array}$ & $\begin{array}{c}\text { Coronary } \\
\text { artery disease, } \\
\text { diabetes } \\
\text { mellitus, } \\
\text { cerebrovascula } \\
\text { r disease } \\
\end{array}$ & $\begin{array}{l}\text { Hypertensi } \\
\text { on }\end{array}$ & $\begin{array}{l}\text { Diabetes } \\
\text { mellitus }\end{array}$ & $\begin{array}{l}\text { Hypertension, } \\
\text { cholelithiasis }\end{array}$ & $\begin{array}{c}\text { Diabetes } \\
\text { mellitus, } \\
\text { cerbrovascul } \\
\text { ar disease }\end{array}$ & $\begin{array}{l}\text { Hypertensi } \\
\text { on, } \\
\text { coronary } \\
\text { artery } \\
\text { disease }\end{array}$ & Hypertension & $\begin{array}{l}\text { Hypertension, } \\
\text { cerebrovascula } \\
\text { r disease }\end{array}$ & Hypertension \\
\hline \multicolumn{2}{|c|}{ Smoking } & No & No & No & No & No & No & No & No & Yes & No & Yes \\
\hline \multicolumn{2}{|c|}{$\begin{array}{l}\text { Time between CLL and non } \\
\text { hematologic } \\
\text { malignancy (months) }\end{array}$} & 88 & 71 & 20 & 21 & $\begin{array}{l}\text { Diagnosed at } \\
\text { the same } \\
\text { time period }\end{array}$ & 96 & 132 & $\begin{array}{l}\text { Diagnosed } \\
\text { at the same } \\
\text { time period }\end{array}$ & 15 & 120 & 11 \\
\hline \multicolumn{2}{|c|}{ Survival (months) } & 21 & $\begin{array}{l}\text { Not } \\
\text { reached }\end{array}$ & 105 & $\begin{array}{l}\text { Not } \\
\text { reached }\end{array}$ & 1 & 103 & 133 & 2 & Not reached & Not reached & Not reached \\
\hline \multicolumn{2}{|c|}{ Cytogenetics } & $\begin{array}{c}\text { ATM } \\
\text { deletion } \\
83.5 \%, \\
\text { del(13q) } \\
83.4 \% \\
\end{array}$ & $\begin{array}{l}\text { Normal } \\
\text { karyotyp } \\
\quad \mathrm{e}\end{array}$ & $\begin{array}{c}\text { Normal } \\
\text { karyotype }\end{array}$ & $\begin{array}{l}\operatorname{del}(13 q) \\
57.13 \%\end{array}$ & $\begin{array}{c}\text { Normal } \\
\text { karyotype }\end{array}$ & $\begin{array}{c}\text { Normal } \\
\text { karyotype }\end{array}$ & $\begin{array}{c}\text { Normal } \\
\text { karyotype }\end{array}$ & Not done & $\begin{array}{l}\text { ATM deletion } \\
97.56 \% \\
\text { del(13q) } \\
96.33 \%\end{array}$ & $\begin{array}{c}\text { D13S319 } \\
\text { deletion 83\%, } \\
\text { D13S25 } \\
\text { deletion } 70 \%\end{array}$ & $\begin{array}{c}\text { Normal } \\
\text { karyotype }\end{array}$ \\
\hline \multirow[t]{2}{*}{ CLL } & Rai Stage & II & $\mathrm{I}$ & III & II & II & II & I & II & II & 0 & II \\
\hline & $\begin{array}{l}\text { Treatment / } \\
\text { Number of } \\
\text { courses }\end{array}$ & $\begin{array}{l}\text { Fludarabine } \\
\text { plus } \\
\text { cyclophospha } \\
\text { mide / } 6 \\
\text { courses }\end{array}$ & None & $\begin{array}{l}\text { Chlorambucil / } \\
4 \text { courses, } \\
\text { Fludarabine } \\
\text { plus } \\
\text { cyclophospham } \\
\text { ide with } \\
\text { rituximab / } 6 \\
\text { courses }\end{array}$ & $\begin{array}{l}\text { Chlorambu } \\
\text { cil plus } \\
\text { methyl } \\
\text { prednisolo } \\
\text { ne / } 3 \\
\text { courses }\end{array}$ & None & $\begin{array}{l}\text { Chlorambucil } \\
\text { plus methyl } \\
\text { prednisolone / } \\
12 \text { courses }\end{array}$ & None & None & $\begin{array}{c}\text { Fludarabine } \\
\text { plus } \\
\text { cyclophospham } \\
\text { ide with } \\
\text { rituximab / } 6 \\
\text { courses }\end{array}$ & None & $\begin{array}{c}\text { CHOP / } 6 \text { courses, } \\
\text { Fludarabine plus } \\
\text { cyclophosphamide } \\
\text { with rituximab / } 6 \\
\text { courses, } \\
\text { bendamustine / } 4 \\
\text { courses }\end{array}$ \\
\hline \multirow[t]{5}{*}{$\begin{array}{l}\text { Non } \\
\text { hematolo } \\
\text { gic } \\
\text { malignan } \\
\text { cy }\end{array}$} & Type & $\begin{array}{c}\text { Stomach } \\
\text { adenonarcino } \\
\text { ma }\end{array}$ & $\begin{array}{c}\text { Breast } \\
\text { invaziv } \\
\text { ductal } \\
\text { carcinom } \\
\text { a }\end{array}$ & $\begin{array}{l}\text { Skin squamous } \\
\text { cell carcinoma }\end{array}$ & $\begin{array}{c}\text { Breast } \\
\text { unknown } \\
\text { histologica } \\
1 \text { type }\end{array}$ & $\begin{array}{c}\text { Colon } \\
\text { adenocarcino } \\
\text { ma }\end{array}$ & $\begin{array}{l}\text { Endometrium } \\
\text { adenocarcinoma } \\
\text { and ovarian } \\
\text { muscinous } \\
\text { carcinoma }\end{array}$ & $\begin{array}{c}\text { Sigmoid } \\
\text { colon } \\
\text { adenocarcino } \\
\text { ma }\end{array}$ & $\begin{array}{c}\text { Vagen } \\
\text { squamous } \\
\text { cell } \\
\text { carcinoma }\end{array}$ & $\begin{array}{c}\text { Lung } \\
\text { squamous cell } \\
\text { carcinoma }\end{array}$ & $\begin{array}{l}\text { Breast invaziv } \\
\text { ductal } \\
\text { carcinoma }\end{array}$ & $\begin{array}{c}\text { Lung } \\
\text { adenocarcinoma }\end{array}$ \\
\hline & Stage & $\mathrm{T}_{1} \mathrm{~N}_{0} \mathrm{M}_{0}$ & $\mathrm{~T}_{2} \mathrm{~N}_{1} \mathrm{M}_{0}$ & $\mathrm{~T}_{1} \mathrm{~N}_{0} \mathrm{M}_{0}$ & $\mathrm{~T}_{1} \mathrm{~N}_{0} \mathrm{M}_{0}$ & $\mathrm{~T}_{3} \mathrm{~N}_{3} \mathrm{M}_{1}$ & IB Grade 2/IC & $\mathrm{T}_{2} \mathrm{~N}_{0} \mathrm{M}_{0}$ & $\mathrm{~T}_{4} \mathrm{~N}_{3} \mathrm{M}_{1}$ & $\mathrm{~T}_{1} \mathrm{~N}_{0} \mathrm{M}_{0}$ & $\mathrm{~T}_{2} \mathrm{~N}_{1} \mathrm{M}_{0}$ & $\mathrm{~T}_{1} \mathrm{~N}_{0} \mathrm{M}_{0}$ \\
\hline & Chemotherapy & No & No & No & No & No & $\begin{array}{l}\text { Yes (paclitaxel, } \\
\text { carboplatin, } \\
\text { cyclophosphami } \\
\text { de) }\end{array}$ & No & No & $\begin{array}{c}\text { Yes } \\
\text { (gemcitabine, } \\
\text { cisplatin) }\end{array}$ & $\begin{array}{l}\text { Yes (cisplatin, } \\
\text { methotrexate, } \\
\text { 5-fluorouracil } \\
\text { with } \\
\text { tamoxifen) } \\
\end{array}$ & No \\
\hline & Radiotherapy & No & Yes & No & No & No & No & No & No & Yes & Yes & No \\
\hline & Operation & Yes & Yes & No & Yes & No & Yes & Yes & No & No & Yes & Yes \\
\hline
\end{tabular}


Table 2

Laboratory Parameters

\begin{tabular}{|c|c|c|}
\hline Variables & $\begin{array}{l}\text { At CLL diagnosis } \\
\qquad(\text { mean } \pm \mathrm{SD})\end{array}$ & $\begin{array}{c}\text { At non hematologic malignancy } \\
\text { diagnosis } \\
(\text { mean } \pm \text { SD })\end{array}$ \\
\hline Hemoglobin (g/dl) & $11.6 \pm 2.18$ & $12 \pm 2.12$ \\
\hline White blood cell count $\left(\times 10^{9} / \mathrm{L}\right)$ & $99.49 \pm 112.98$ & $27.19 \pm 112.98$ \\
\hline $\begin{array}{l}\text { Absolute Neutrophil } \\
\text { Count }\left(\times 10^{9} / \mathrm{L}\right)\end{array}$ & $14.31 \pm 8.08$ & $8.64 \pm 4.28$ \\
\hline $\begin{array}{l}\text { Absolute Lymphocyte } \\
\text { Count }\left(\times 10^{9} / \mathrm{L}\right)\end{array}$ & $71.1 \pm 78.65$ & $17.09 \pm 25.26$ \\
\hline $\begin{array}{l}\text { Mean Corpuscular Volume } \\
\text { (femtolitre) }\end{array}$ & $82.48 \pm 7.7$ & $87.31 \pm 8.76$ \\
\hline Platelet $\left(\times 10^{9} / \mathrm{L}\right)$ & $293.5 \pm 118.5$ & $254.55 \pm 167.79$ \\
\hline $\begin{array}{l}\text { Erythrocyte Sedimantation } \\
\text { Rate }(\mathrm{mm} / \mathrm{h})\end{array}$ & $34.28 \pm 30.99$ & $14.5 \pm 11.03$ \\
\hline C Reactive Protein (mg/dl) & $1.2 \pm 1.78$ & $0.48 \pm 0.19$ \\
\hline Beta 2 microglobulin & $2.07 \pm 2.02$ & $0.76 \pm 0.2$ \\
\hline Immunglobulin $\mathrm{G}$ (mg/dl) & $1172.5 \pm 532.55$ & $624.5 \pm 195.86$ \\
\hline Immunglobulin A (mg/dl) & $212.2 \pm 90.84$ & $45.95 \pm 34.86$ \\
\hline Immunglobulin $\mathrm{M}$ (mg/dl) & $61.5 \pm 45.26$ & $23.7 \pm 20.56$ \\
\hline Glucose (mg/dl) & $115.33 \pm 20.95$ & $138.62 \pm 78$ \\
\hline BUN (mg/dl) & $24.85 \pm 15.51$ & $32.57 \pm 0.49$ \\
\hline Creatinine (mg/dl) & $1.15 \pm 0.49$ & $1.32 \pm 0.87$ \\
\hline $\operatorname{AST}(\mathrm{U} / \mathrm{L})$ & $17.66 \pm 5.53$ & $21.85 \pm 9.83$ \\
\hline ALT (U/L) & $13.5 \pm 7.25$ & $30.42 \pm 32.1$ \\
\hline ALP (U/L) & $489.66 \pm 456.77$ & $258 \pm 56.65$ \\
\hline GGT (U/L) & $46.66 \pm 75.69$ & $32.33 \pm 20.38$ \\
\hline LDH (U/L) & $631.16 \pm 448.15$ & $407.5 \pm 130.64$ \\
\hline Üric acid (mg/dl) & $5.42 \pm 2.16$ & $5.42 \pm 1.68$ \\
\hline Calcium (mg/dl) & $9.35 \pm 0.75$ & $9.36 \pm 0.65$ \\
\hline Phospor (mg/dl) & $3.71 \pm 0.68$ & $3.42 \pm 0.82$ \\
\hline Total bilirubin (mg/dl) & $0.62 \pm 10.16$ & $0.66 \pm 0.38$ \\
\hline Total protein (mg/dl) & $6.64 \pm 0.31$ & $6.58 \pm 0.31$ \\
\hline Albumin (mg/dl) & $3.9 \pm 0.86$ & $4.4 \pm 0.61$ \\
\hline
\end{tabular}

CLL: Chronic Lmphocytic Leukemia, SD: Standard Deviation

\section{Discussion}

CLL is associated with an increased risk of developing both solid tumours and other lymphoid malignancies. Several mechanisms have been discussed for the association between CLL and second cancers including disease related and treatment related immunosuppression and shared risk factors (4). B lymphocyte defects, low gammaglobulin levels and quantitative and functional $\mathrm{T}$ cell defects have been documented in the setting of CLL (5). We don't know about the B and
T lymphocyte defects but our patients didn't have low gammaglobulin levels and a non hematologic malignancy developed in 4 of our patients despite receiving no treatment for CLL. Environmental exposures and heritable factors of our patients were not recorded but 10 of our 11 patients were evaluated cytogenetically and del 13q and/or ATM deletion was found in 4 of 10 patients. Van den Broek et al (3) found $10 \%$ of all newly diagnosed CLL patients had a prior malignancy and cancer survivors had a $90 \%$ higher risk to be diagnosed with CLL than the general 
population. The median interval between first primary malignancy and a second cancer was 3 years. Therapy for a prior cancer did not increase the risk of CLL. The short time period between CLL and non hematologic malignancy may suggest a shared common risk factor. However, the time between two diagnosis was 11132 months in our patients and 2 patients were diagnosed simultaneously. At least two studies $(6,7)$ found little evidence to suggest an association between treatment and subsequent development of second cancers. Chlorambucil is not very immunosuppressive. It is considered leukemogenic but this effect is particularly observed during the treatment of myeloproliferative disorders (4). However, the first line treatment of CLL is changing towards a more aggressive therapy with purine analogue/alkylator/rituximab combination. This combination is very immunosppressive (8). Chlorambucil, fludarabin, cyclophosphamide \pm rituximab and CHOP (cyclophosphamide, doxorubicine, vincristine, methyl prednisolone) were the regimens our patients received before CLL diagnosis. Only 2 patients had a non hematologic malignancy diagnosis before CLL. Two or even 3 second malignancies in CLL patients have been reported with increased frequency (9). To our knowledge, neither CLL and endometrial carcinoma and ovarian carcinoma in the same patient nor CLL and vaginal carcinoma in the same patient has been reported before. Patients with CLL have an increased risk of non melanoma skin cancer $(6,10,11)$. Patients having a high Rai stage at the time of their skin cancer diagnosis were 4.5 times more likely to develop skin cancer outcomes compared with patients having a low Rai stage (11). Our patient with skin squamous cell carcinoma received a 3 month course of chlorambucil and methyl prednisolone and was in Rai stage III. The time between two diagnosis were 20 months. The cause of death was neither CLL nor BCC in this patient. Lee et al
(12) reported an incidentally identified colon cancer in a male with newly diagnosed CLL during initial staging with whole body positron emission tomography (PET) scanning with fluorine -18 fluorodeoxyglucose $\left({ }^{18} \mathrm{~F}-\mathrm{FDG}\right)$. Two of our patients had colon carcinoma one diagnosed simultaneously and the other 132 months after CLL. One was not suitable for treatment and the other refused therapy. As a result the survival after colon cancer diagnosis was only 1 month in both patients. In general, CLL is not regarded as a radiation-induced cancer $(13,14)$. However, controversies in this issue persist $(13,14)$. Three of our patients received radiotherapy. CLL was the first malignacy in two of them and the second malignancy only in one. Parekh et al (9) has shown that approximately $2 \%$ of patients with CLL develop lung carcinomas and $85 \%$ of the lung cancer patients were smokers. The diagnosis was made approximately 8 years after the diagnosis of CLL. Our both patients with lung cancer (one with squamous cell carcinoma and the other adeno carcinoma) were smokers but they still do well with both CLL and lung cancer. This may be due to the early stage at diagnosis. They were both diagnosed only one year after CLL diagnosis and they both received fludarabin, cyclophosphamide plus rituximab. In some previous studies, the increased risk of lung cancer was found to be independent of time since CLL diagnosis leading to the conclusion that it could not be attributed to CLL treatment $(16,17)$. However, concomitant with the introduction of the nucleoside analogues, some studies reported increased risk of lung cancer (18-20). In conclusion, patients with CLL may also have a non hematologic malignancy. The non hematologic malignancy may occur before or after CLL diagnosis and sometimes simultaneously. This coincidence may ocur in patients who either received a chemo or radiotherapy for malignancy or not. Although the role of shared etiological factors remains unclear, 
patients with CLL should be carefully evaluated in terms of non hematologic malignancy during initial staging and follow-up period. Reporting more patients having both CLL and a non-hematologic malignancy can add new insights into the role of casual factors and treatment options.

\section{REFERENCES}

1. Ng, A.K. Travis, L.B. (2008). Second primary cancers: an overview. Hematol Oncol Clin N Am. 22:271-89.

2. Gribben, J.G. (2010). Chronic lymphocytic leukemia: planning for an aging population. Expert Rev Anticancer Ther. 10: 1389-1394.

3. van den Broek E.C. Liu, L. (2014). Posthuma EFM, et al. Increased risk of chronic lymphocytic leukemia among cancer survivors in the Netherlands: increased detection, casual factors or both? Ann Hematol. 93: 157-162.

4. Royle, J.A. Baade, P.D. Girschik, J. Fritschi, L. (2011). Second cancer incidence and cancer mortality among chronic lymphocytic leukaemia patients: a population based study. Br J Cancer. 105:1076-1081.

5. Dasanu, C.A. Alexandrescu, D.T. (2007). Risk for second nonlymphoid neoplasms in chronic lymphocytic leukemia. Med Gen Med. 9:35.

6. Tsimberidou, A.M. Wen, S. McLaughlin, P. et al. (2009). Other malignancies in chronic lymphocytic leukemia/small lymphocytic lymphoma. J Clin Oncol. 27:904-910.

7. Callea, V. Brugiatelli, M. Stelitano, C. et al. (2006). Incidence of second neoplasia in patients with $\mathrm{B}$ cell chronic lymphocytic leukemia treated with chlorambucil maintenance chemotherapy. Leuk Lymph. 47:23142330.

8. Carney, D.A. Mulligan, S.P. (2009). Chronic lymphocytic leukemia: current first line therapy. Intern Med J 39:44-48.
9. Parekh, K. Rusch, V. Kris, M. (1999). The clinical course of lung carcinoma in patiets with chronic lymphocytic leukemia. Cancer. 86:1720-1723.

10. Otley, C.C. (2006). Non Hodgkin lymphoma and skin cancer: a dangerous combination. Australas $J$ Dermatol. 47:231-236.

11. Levi, F. Randimbison, L. Te, V.C. La Vecchia, C. (1996). Non Hodgkin's lymphomas, chronic lymphocytic leukemias and skin cancers. $\mathrm{Br} J$ Cancer. 74:1847-1850.

12. Velez, N.F. Karia, P.S. Vartanov, A.R. et al. (2014). Association of advanced leukemic stage and skin cancer tumor stage with poor skin cancer outcomes in patients with chronic lymphocytic leukemia. JAMA Dermatol. 150:280287.

13. Lee, J.E. Bae, S.M. Kim, M.S. et al. (2013). Positron emission tomography detection of synchronous colon cancer in a patient with chronic lymphocytic leukemia. Korean $J$ Intern Med. 28:500-503.

14. Curtis, R.E. Boice, J.D. Jr Stovall, M. et al. (1994). Relationship of leukemia risk to radiation dose following cancer of the uterine corpus. J Natl Cancer Inst. 86:1315-1324.

15. Brenner, D. J. Curtis, R. E. Hall, E. J. Ron, E. (2000). Second malignancies in prostate carcinoma in patients after radiotherapy compared with surgery. Cancer. 88: 398-406.

16. Hamblin, T. J. (2008). Have we been wrong about ionizing radiation and chronic lymphocytic leukemia? Leuk Res.32: 523-525. 
17. Richardson, D.B. Wing, S. Schroeder, J. et al. (2005). Ionizing radiation and chronic lymphocytic leukemia. Environ Health Perspect.113: 1-5.

18. Hisada, M. Biggar, R.J. Greene, M.H. et al. (2001). Solid tumors after chronic lymphocytic leukemia. Blood. 98:1979-1981.

19. Mellemgaard, A. Geisler, C.H. Storm, H.H. (1994). Risk of the kidney cancer and other second malignancies in patients with chronic lymphocytic leukemia. Eur J Haematol. 53:218-22.

20. Kyasa, M.J. Hazlett, L. Parrish, R.S. et al. (2004). Veterans with chronic lymphocytic leukemia/small lymphocytic lymphoma have a markedly increased rate of second malignancy, which is the most common cause of death. Leuk Lymph. 45:507-513. 